\title{
Die Hervormde Kerk: Soekend na 'n weg tussen ekklesiologiese verstarring en innovasie sonder tradisie
}

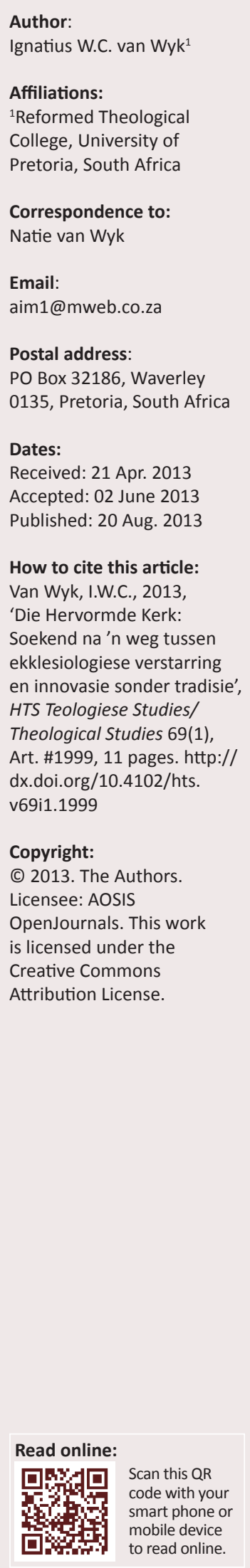

The Netherdutch Reformed Church of Africa: Searching for a road between ecclesiological petrifaction and innovation without tradition. This article is a critical contribution to the discourse in the Netherdutch Reformed Church of Africa on ecclesiology. In preparation for the next synod meeting in September 2013, the church is confronted by many discussion papers. This article is a plea to return to the basic ecclesiological perspectives of the Early Church and the Reformation. Where this is not done, unbiblical ideas creep into the church. Concentration falls on eschatological character, catholicity, the offices and the calling of the church. Continued attention is given to the notion 'people's church'.

\section{Inleiding}

Die Nederduitsch Hervormde Kerk van Afrika (NHKA) is besig om te verklein en te verarm (vgl. Struwig 2013; Ungerer 2013; D.J.C. van Wyk jr. 2013; W. van Wyk 2013b). 'n Magdom van redes kan vir hierdie toestand opgenoem word soos swak bediening, veroudering, geringe aanwas, emigrasie, afskeiding, disassosiasie en ongeloof. Die NHKA deel ook in die lotgevalle van die 'Westerse Christendom' wat ly onder magte soos sekularisasie, pluralisme en die heerskappy van wetenskaplik-tegniese denke (vgl. Jenkins 2007). Ekklesiologiese besinnings is op hierdie stadium van die Kerk se geskiedenis baie belangrik. ${ }^{1}$ Vanuit 'n verskeidenheid van perspektiewe en teologiese oortuigings moet bydraes aangebied word, sodat die besluitnemende vergaderings van die Kerk ingeligte besluite oor die pad vorentoe sal kan neem (vgl. Barnard 2013; Van Staden 2013; D.J.C. van Wyk jr. 2013; W. van Wyk 2013a, 2013b). Hierdie bydrae wil lesers terugvoer na die wortels van die 'Bybels-Reformatoriese ekklesiologie' ${ }^{2}$ - of verkieslikdie 'evangeliese teologie'. Ek meen dit is op hierdie stadium belangrik om terug te keer na rigtinggewende uitsprake van die kerkvaders en kerkhervormers. Op voetspoor van die filosoof Odo Marquard (2003) wil ek daarop wys dat 'toekoms, herkoms nodig het'. 'n Besinning oor toekomsperspektiewe kan nie sonder die rigtinggewende perspektiewe van die verlede klaarkom nie. Nadat ons weer helderheid het oor waar die $\mathrm{K}(\mathrm{k})$ erk vandaan kom, kan en moet ons poog om verder te dink. Ons word tans meegesleur deur 'liberaal-charismatiese' oortuigings (vgl. o.a. J. Beukes 2012 en Strauss 2013) wat nie op die lang duur die welsyn van die NHKA sal dien nie. 'n Ekklesiologie wat aansluiting vind by die vertrekpunte van die Vroeë Kerk en die Reformasie het ' $n$ beter kans om standhoudende oplossings vir die toekoms te bedink. Só 'n benadering is in pas met die oorspronklike betekenis van die woord 'reformasie'. Die begrip reformatio is sedert die twaalfde eeu gebruik om 'n proses aan te dui wat die kerklike denke terugneem na die ou, oorspronklike dinge. Martin Luther het hierdie term die eerste keer in 1518 gebruik in die resolutiones (conclusio 89) tot die teses oor die aflaat. Dáár het hy ook gevra vir 'n terugkeer na die ou Christelike waarheid, maar geweet dat dit slegs kan gebeur deur 'n terugkeer na die purissima studia van die Skrif (Eckert [1968] 2012:516). My vraag is: Waarnatoe kan ons terugkeer? Dit wat sedert die vyftigerjare van die vorige eeu uitgekristaliseer het as 'Hervormde ekklesiologie'? Nee, ons moet terug na die groter Reformatoriese tradisie en die Vroeë Kerk. Wat die NHKA as 'ekklesiologiese tradisie' opgebou het, is té klein, onbenullig en selfs bedenklik. Ons sal moet hervorm - en dít beteken om die bronne van die tradisie waarop ons roem, te (her)ontdek. In hierdie proses sal ons gedwing word om krities oor ons eie doen en late te dink en om verruimend oor die weg die toekoms in te besin.

Die positiewe van die 'Hervormde teologie' was nog altyd te vinde in ons ruimgeestigheid om impulse uit die Wittenbergse Reformasie op te neem. Die negatiewe het met ons gebrekkige

1.Wolfhart Pannenberg (1993:33-40) het die tese opgestel dat 'ekklesiologie' as teologiese dissipline eers vanaf die sestiende eeu ontwikkel het. Vóór hierdie datum is daar wel akademiese aandag aan die sakramente en ampte gegee, maar die kerk as sodanig het eers vanaf die negentiende eeu aandag begin geniet toe besef is dat die kerk bloot as' $n$ instituut naas ander institute in die samelewing gesien word. Toe die kerk haar belangrike posisie in die samelewing moes prysgee, is daar veral na 1848 begin vra na die funksie en publieke rol van kerk. In die twintigste eeu het ' $n$ magdom publikasies oor die ekklesiologie die lig gesien (cf. Van den Brink \& Van de Kooi 2012:518 vir'n lys van die belangrikste publikasies). Bram van de Beek (2012:21-22) wys egter tereg daarop dat die kerkvaders en die Middeleeuse teologie baie groot aandag aan die leer oor die kerk gegee het. Die Christelike geloof is nooit buite die kerk om bedink nie. Uitsprake soos die 'kerk is ons moeder' was algemeen gebruikte taal en nie geïsoleerde uitsprake nie. Die oortuiging dat Christus by die Nagmaal teenwoordig is, was altyd ' $n$ belangrike aspek van die geloof. Gewoon op grond van hierdie argument is dit nie waar dat ekklesiologie ' $n$ laatkommer in die teologiese ensiklopedie is nie. In navolging van Van de Beek word in hierdie artikel teruggegryp op belangrike uitsprake van die vroeë en Reformatoriese kerkvaders.

2.Die tradisionele term 'Bybels-Reformatories' bevat ' $n$ toutologie. Reformatoriese impliseer Bybels. Ek verkies eerder die term 'evangeliese teologie' - soos Karl Barth aanbeveel het (Die tydskrif EvangelischeTheologie het op aandrang van Barth die lig gesien). 
identifikasie met die breëre Gereformeerde Protestantisme ${ }^{3}$ te make. Daar is beslis altyd ruimte vir partikulariteit, maar 'n Hervormde kerk wat nie begaan is oor 'n algemene Hervormde identiteit nie, is ontrou aan haar eie tradisie. Formulerings uit minder bekende Gereformeerde belydenisskrifte word daarom, doelbewus, bekendgestel. Deur dít te doen, gee ons blyke daarvan dat die belydenis oor die katolisiteit van die kerk ernstig opgeneem word - 'n aspek wat in hierdie artikel deeglik aandag sal geniet.

Slegs 'n ecclesia semper reformanda is ware kerk (Theißen 2012:280). Ook die NHKA sal moet hervorm - maar nie met behulp van nuwe, eksperimentele dinge uit die Pinksterbeweging nie (vgl. J. Beukes 2012; Strauss 2013), maar deur die herontdekking van wat ons vergeet het en of nog nooit van ons eie tradisie geweet het nie. Die Duitse Evangeliese Kerk, die 'moederkerk van die Reformasie' en die grootste Protestantse kerk, is ook besig met'n omvattende proses van herbesinning. Juis by hulle kan mens leer hoe kerkvernuwing geskied deur die herontdekking van tradisie (vgl. o.a. Huber 2007, 2009; Hermelink 2011).

Talle mense wat nog 'n band met die kerk wil handhaaf, het nie meer waardering vir tradisies en die tradisie-argument nie. Liberale Protestante soos Peter Berger (2004:130-143) meen dat lidmaatskap van 'n kerk 'n kwessie van die wilsbesluit (vocation) van ' $\mathrm{n}$ individu is. Elke persoon moet besluit waar hy of sy wat wil hoor. Tradisionele kerke het ongeloofwaardig geraak en hulle tradisies maak nie juis indruk op tydgenote nie. ' $n$ Hele nuwe kerklike bedeling moet dus geskep word. Gerd Theißen (2012:11-13, 305), 'n ander liberale teoloog, dink egter anders oor tradisie. Volgens hom kan en mag dit nie eenvoudig van die tafel gevee word nie. Daar moet respek wees vir die Bybel en die kerklike leertradisie, en in sy geval die Hervormde tradisie - so nie sal die kerk niks te sê hê nie. Binne die werklikhede van die Aufklärung moet die kerk egter poog om met die gesekulariseerde bevolking dialoog te voer oor die Bybel en die leertradisie; maar dan met behulp van Lessing, Schleiermacher en Schweitzer.

Daar is talle aspekte van die ekklesiologie wat ons aandag op hierdie stadium verdien. 'n Mens sou kon besluit om een of twee sake, diepgaande en koherent te bespreek. Hier word eerder ' $n$ 'postmoderne' benadering gevolg om verskillende relevante sake vlugtig, maar uitdagend te bespreek.

\section{Wat glo ons van 'Die' Kerk?}

Volgens die teks van die Niceense Geloofsbelydenis in die Diensboek van die NHKA (2008:125) 'glo ons een, heilige,

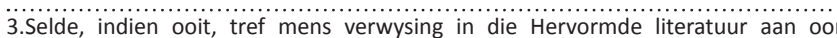
die inhoude van byvoorbeeld Gereformeerde belydenisskrifte buiten die 'drie formuliere van eenheid'. Een van die lastighede waarmee ons egter gekonfronteer word, is dat ons nie oor 'n Gereformeerde of Hervormde corpus doctrinae beskik nie. Dit is dus nie so maklik om te sê wat Hervormde ekklesiologie is nie - in teenstelling tot die Lutherane wat oor' $n$ belydeniskanon, die Concordia, beskik. Die Lutherane kan makliker sê wat Lutherse ekklesiologie is. My bydrae het dus ten Lutherane kan makliker se wat Lutherse ekklesiologie is. My bydrae het dus ten doel om die verborge skatte van die bree Hervormde tradisie te herwin. Hierdie 'skatte' kan nagespeur word in die oorspronklike korpus, bekend as die Harmonia confessionum fidei orthodoxarum et reformatarum ecclesiarum, gepubliseer in Latyn in 1581 en algemeen bekend as Salnar se Harmonia Confessionum Fide (Duits 1887). Hierdie harmonie van Gereformeerde belydenisskrifte is in 1586 in Engels vertaal en in Cambridge gepubliseer. Deur die eeue is meer versameling gepubliseer - die nuutste die bundel wat deur Cochrane (2003) saamgestel is. algemene kerk, gegrond op die leer van die apostels.' Hierdie aangepaste weergawe word as geldige teks aangebied op grond van 'n gewaardeerde uitlegtradisie. Calvyn het byvoorbeeld geleer dat ons nie 'aan die kerk glo nie' omdat ons nie ons vertroue op die kerk kan plaas nie: 'Wanneer ons betuig dat ons aan God glo, dan verlaat ons ons in vertroue op Hom, en dít geld nie die kerk nie' ('ideo enim credere in Deum nos testamur, quod [...] fiducia nostra in ipso acquiescat; quod in Ecclesiam non ita conveniret') (Inst IV, 1, 2 = Calvyn [1559] 1992:1268).

Volgens Calvyn glo ons nie aan die kerk as iets Goddelik nie. Die belydenis aangaande die kerk is nie ' $n$ vierde artikel van die geloof nie. Wat Calvyn dan byvoeg, is 'n belangrike saak. Hy sê om kerk te glo is 'om vas oortuig te wees dat ek daarvan ' $n$ lid is' ('ut certo persuasi simus nos esse eius membra') (Inst IV ,1,3 = Calvyn [1559] 1992:1269). Kerk is daarom nie 'n abstraksie losgekoppel van mense se geloof en deelname nie. Anders gestel: slegs diegene wat aan die kerk wil deelneem, sal glo dat daar ' $n$ kerk is wat deur God byeen gebring is. Nog anders: diegene wat in Christus glo, sal ook in sy kerk glo. Die slagspreuk 'ja vir Christus - nee vir sy kerk' is nie teologies houdbaar nie (Busch 2003:248-249).

Hierdie uitlegtradisie berus egter op 'n Latynse vertaling (credo ecclesiam [ek glo die kerk]) van die oorpronklike Griekse teks van die Nicaeno-Constantinopolitanum (381) wat gelees het 'ons glo aan of in (eis) die kerk'. Interessant is dat die Protestantse Kerk in Nederland (PKN) teruggekeer het na die oorspronklike weergawe. Die Nederlanders meen, en ons kan hulle hierin volg, dat, in die tyd van kerklike verval, dit nodig geword om die klem weer op die kerk as Goddelike inisiatief te plaas. Die oortuiging moet bevorder word dat Christus sy kerk skep, onderhou en beskerm (soos destyds tydens die martelaarskap in die Vroeë Kerk). Christene moet weer geleer word om te midde van bedreigende omstandighede en in tye van verval, hulle ten volle op Christus te verlaat (Van den Brink \& Van der Kooi 2012:520-521).

\section{Kerk van die kruis}

Daar is tans aandrang dat daar op die 'positiewe' gekonsentreer moet word in aanloop na die volgende sinode (vgl. D. Beukes 2012). Enkele persone vul ongelukkig die 'positiewe' met die woord 'sukses' (vgl. Strauss 2013). Dit lyk of ons met 'n nuwe theologia gloria gekonfronteer word. 'n Reformatoriese kerk is tog ' $n$ kerk van die kruis. Die sentrum van die prediking is die kruis (1 Kor 1:23), die kerk bestaan onder die kruis en die lidmate dra daagliks die kruis (Luk 9:23). Kruis impliseer lyding. Luther het in 1541 in sy geskrif Wider Hans Worst, lyding selfs as 'n kenmerk van die ware kerk beskou (vgl. Lohse 1995:303). Om kerk te wees beteken om lyding en swaarkry te ervaar. Dit beteken om strydende kerk te wees. Om kerk van die kruis te wees beteken ook om 'n kerk van medelyde te wees. 'n Kerk wat nie saam die las wil dra nie; nie met ander wil deel nie, is nie kerk van Christus nie. Waarna gestreef moet word, is nie 'n paar blink, 'suksesvolle' gemeentes nie, maar sterk gemeentes wat die swak gemeentes sal dra met gebede en bystand (vgl. Plasger 
2008a:114-115; Plantinga, Thompson \& Lundberg 2010:356358; Van de Beek 2012:24-29).

\section{Die Kerk is ons moeder}

Die beeld wat talle mense van die NHKA voor oë het, is dié van 'n sinkende skip (Struwig 2013). Die vermindering en veroudering van lidmate en die gepaardgaande finansiële agteruitgang skep 'n situasie van wanhopigheid. Daar bestaan 'n skool van denke in die Kerk wat meen dat ons van 'n georganiseerde instituut afstand moet doen. Geloof moet maar in huise en op straat uitgeleef word. Ons moet op die 'onsigbare kerk' en die 'koninkryk' gerig wees en die skip maar verlaat om te sink (vgl. D.J.C. van Wyk 2012; W. van Wyk 2013a). Hierdie is nie 'n Bybelse siening van sake nie. Die klassieke beelde van die kerk vertel 'n totaal ander verhaal.

Die beeld van die kerk as die 'moeder van die gelowiges' verdien op hierdie tydstip spesiale aandag. Cyprianus (De unitate ecclesiae 6 soos opgeneem in MPL 4:503; vgl. ook Van de Beek 2012:17-18) was een van die eerste kerkvaders wat gesê het: 'Wie die kerk nie as moeder wil aanvaar nie, kan God nie as Vader beskou nie (Habere iam non potest Deum patrem qui ecclesiam non habere matrem'). Calvyn (Inst IV, 1, 4 = Calvyn [1559] 1992:1271-1272) het hom by Cyprianus aangesluit en op sy beurt gesê, 'wie God as Vader het, moet ook die kerk as moeder hê.' Dit is egter minder bekend dat Calvyn hierdie beeld binne 'n wyer konteks gebruik het. Hy (Inst IV , 1, 4, 4-6 = Calvyn [1559] 1992) het gesê:

Daar is trouens geen ander toetrede tot die lewe tensy die kerk ons in haar skoot ontvang, aan ons geboorte skenk, ons aan haar borste voed en ons onder haar beskerming en leiding bewaak totdat ons ons sterflike vlees afgelê het nie ... (quando non alius est in vitam ingressus nisi nos ipsa concipiat in utero, nisi pariat, nisi nos alat suis uberibus, denique sub custodia et gubernatione sua nos tueatur, donec exuti carne mortali ...). (bl. 1271)

Hierdie beeld wil dus kommunikeer dat die bestaan van die kerk die persoonlike geloof voorafgaan. Private geloof is dus nie moontlik nie; dit kan slegs 'kerklike geloof' wees, indien dit Christelik wil wees. Weer eens - die slagspreuk 'ja vir Christus - nee vir die kerk' is totaal onvanpas (Huber 2009:160-163). Ewe belangrik is Calvyn se argument dat ons via die kerk as ons moeder deel kry aan die lewe in sy volheid. Hy (Inst IV, 1, 4; Plasger 2008b:310) verduidelik hierdie stelling onder andere met die gedagte dat daar 'buite die kerk geen vergewing van sondes of heil te wagte nie.' Van de Beek (2012:184-191) is reg deur te sê dat Calvyn bedoel dat 'buite die kerk ons die evangelie nie vind nie.' Hierdie beelde handel dus nie oor ' $n$ toornige God wat diegene buite die kerk wil vernietig nie, maar oor moederlike versorging van hulle wat op soek is na vreugde en vertroosting. Die belangrikste van hierdie beeld is dat die kerk die bewaarder en beskermer van die gelowiges is. Gelowiges is dus nie uitgelewer aan die magte en kragte van hierdie wêreld nie, maar word moederlik versorg deur die Hoof van die kerk wat aan almal lewe in volheid wil skenk. Dit is binne hierdie raamwerk dat daar na finansiële besparingsmaatreëls gekyk moet word. Rade en strukture moet funksioneel wees.
Organisatoriese maatreëls en strukture is nie onveranderlik nie. Enige mensgemaakte inrigting van kerklike sake kan verander en aangepas word. As die afskaffing van bepaalde administratiewe en finansiële instellings en strukture die kerk egter in die uitlewing van haar roeping gaan belemmer, moet dit nie oorhaastig gedoen word nie. Daar moet geglo word dat ook die NHKA onder die leiding en beskerming van die Heilige Gees staan. Ons moet besef dat buite die mure van die georganiseerde kerk die evangelie selde indien ooit te vinde is. My argument is dus nie gerig téén besparing en herstrukturering nie, maar téén ongeloof en kleingeloof in die moederlike liefde van die Hoof van die kerk en die geringskatting van die belangrikheid van die sigbare kerk.

Georg Plasger (2008a) se mooi samevatting van Calvyn se ekklesiologie sê dalk duideliker wat betoog word:

Die Kirche ist von Gott erwählt - und deshalb zunächst zu glauben und nicht $\mathrm{zu}$ sehen. Aber als geglaubte Kirche ist sie auch die zu gestaltende Kirche, weil sie als Leib Christi ihrem Herrn zu entsprechen hat - und weil sie die Aufgabe hat, die Gemeinschaft mit Christus zu leben. Deshalb gibt sie sich Ordnungen, die aber an die jeweiligen Erfordernisse anzupassen sind. In allen auf dem Weg zu erwartenden Anfechtungen darf sie auf den Schutz Gottes hoffen. (bl. 107)

\section{Die Kerk is nie identifiseerbaar nie maar tog aanwysbaar}

Ten spyte van die feit dat die kerk aanwysbaar of sigbaar is, is dit egter nie identifiseerbaar nie. Die kerk word geglo omdat dit onsigbaar is. Slegs God ken die grense van die kerk. Volgens Calvyn (Inst IV, 1, 2, 37-38 = Calvyn [1559] 1992:1268) 'moet ons dit aan God alleen oorlaat om sy kerk te ken omdat die grondslag daarvan sy verborge uitverkiesing is' (soli Deo permittenda est cognitio suae Ecclesiae, cuius fundamentum est arcana illiuis electio). Die onsigbaarheid hang met die katolisiteit saam aangesien die gemeenskap van gelowiges ons voorgeslagte en nageslagte reg oor die wêreld insluit. Om staat te maak op God se universele uitverkiesing is belangrik, maar dit is ewe belangrik om aan die kerk se gestaltegewing aandag te gee (Plasger 2008b:319-320). Vergaderings, rade en institute is nie van wesenlike belang nie, maar die kerk kan ook nie algeheel daarsonder klaarkom nie. Die kerk as organisasie is nie 'n doel in sigself nie aangesien dit as werktuig van die Heilige Gees daarop uit is om in vriendelikheid mense uit te nooi om in gemeenskap met Christus te tree. Calvyn (vgl. Plasger 2008a:107-108, 2008b:317-319) het Boek IV van sy Institusie, wat oor die ekklesiologie handel, onder die hoofopskrif 'uitnodiging' (invitatio) geplaas. Hiermee wou hy aandui wat die funksie van die sigbare kerk is. Die kerk is volgens Calvyn gekies om die uitverkorenes, op grond van 'n vriendelike uitnodiging, te versamel en te bewaar, te leer en te orden. Dít doen die kerk omdat die Drie-enige God mense op hierdie wyse uitkies om sy kerk te wees. Pragtig sê hy (Inst IV , 1, 3 = Calvyn [1559] 1992:1271) dat die uitverkorenes, die kerk, 'diegene is wat deur die vriendelikheid van God die Vader deur die werking 
van die Heilige Gees in gemeenskap met Christus gebring is' ('omnes eos qui Dei patris clementia per spiritus sancti efficaciam in Christi participationem venerunt').

Die kerk het dus 'n duidelike funksie, en om hierdie funksie uit te voer is organisasie en strukture nodig. Geen enkele struktuur is egter heilsnoodwendig nie, maar talle strukture bly onontbeerlik aangesien dit 'tot opbou van die gemeente dien' ('ad ecclesiae aedificationem') (Inst IV, 10,32 = Calvyn [1559] 1992:1499-1500; Plasger 2008b:324). In hierdie tyd waar bespaar en gerasionaliseer moet word, sal daar baie versigtig gekyk moet word na wat afgeskaf en wat behou moet word - met die vraag in gedagte: Dien dit die vriendelike uitnodiging om deel te neem of nie?

Herstrukturering, afskaffing en verandering is gekompliseerde aangeleenthede en daar moet versigtig gehandel word. Die emosionele debat oor 'volkskerk' is 'n goeie voorbeeld (vgl. Willemse 2012). Gister het 'volkskerk' ingepas by die sosiale realiteite. Vandag pas dit nie meer gemaklik in by die veranderde werklikhede nie. Die vraag is of ons blindweg en oorhaastig die hele gedagte van die tafel moet vee? Peter Berger (2004:139) verdedig die 'AfroAmerikaanse apartheidskerke' met die argument dat dit vir hulle ' $n$ veilige hawe is waar hulle hul volle menslikheid kan belewe. Die vraag is, hoekom geld dieselfde argument nie vir die (plattelandse) Afrikaner nie - óf mag hierdie vraag nie gevra word nie? Hoekom geld 'n argument vir een groep, maar nie vir ' $n$ ander groep nie? Hiermee verdedig ek nie die ou 'volkskerkgedagte' nie, maar stel dat dit in hierdie saak om méér as verkeerde ekklesiologie gaan. Dit gaan ook om die menslike waardigheid van (sekere) mense wat hulle self minderwaardig voel teenoor ander.

\section{Die Kerk as eskatologiese gemeenskap}

Een van die groot dilemmas waarvoor die NHKA staan het met die werklikheid te make dat haar verlede, enersyds, onlosmaaklik aan die nasionalistiese strewes van die Afrikaner verbonde is, maar dat sy andersyds tog ook kerk wil wees op voetspoor van die Bybel en Bybelse teologie. Die verknogtheid aan die aardse ideale van volk, kultuur en land is moeilik te versoen met die Bybelse beelde van die kerk as 'n 'swerwende volk' (Heb 13:14) en 'n instelling wat geen permanente staanplek op aarde het nie (2 Kor 5). Die NHKA móét daarom erns maak met die geskrifte uit die Vroeë Kerk wat rigtinggewend is vir die meeste Christene op aarde.

Bram van de Beek (2012) begin sy nuwe boek oor die ekklesiologie met die volgende woorde:

De kerk is de gemeenschap van mensen die niet meer aan zichzelftoebehoren maar aan Christus. Zijvinden hun identiteit in Hem. Zijbehoren niet meer tot de werkelijkheid van deze wêreld, maar tot de eschatologische werkelijkheid van Christus. Daarom zijn zi jwereldvreemd. Hun wezenlijke bestaan is in het eeuwige leven. (bl. 13)
Hiermee sluit Van de Beek aan by die hoofstroom van teologiese denke deur die eeue. Die oortuiging dat die kerk 'n nuwe, unieke skepping of volk is, is klassiek uitgedruk in Hoofstuk 5, 1 van die Diognetus-brief ${ }^{4}$ :

Christians are not different from the rest of men in nationality, speech, or customs; ... They live each in his native land - but as though they were not really at home there. They share in all duties like citizens and suffer all hardships like strangers. Every foreign land is for them a fatherland and every fatherland a foreign land. They marry like the rest of men and beget children, but they do not abandon the babies that are born. They share a common board, but not a common bed. In the flesh as they are, they, however, do not live according to the flesh. They dwell on earth, but they are citizens of heaven. They obey the laws that men make, but their lives are better than the laws. They love all men, but are persecuted by all. They are unknown, and yet they are condemned. They are put to death, yet are more alive than ever. They are paupers, but they make many rich. They lack all things, and yet in all things they abound. They are dishonoured, yet glory in their dishonour. They are maligned, and yet are vindicated. They are reviled, and yet they bless. They suffer insult, yet they pay respect. They do good, yet are punished with the wicked. When they are punished, they rejoice, as though they were getting more of life. In a word, what the soul is to the body, Christians are to the world. (Willis 2002:38-39)

Die apologete het die kerk die 'derde nasie' genoem (vgl. Norris 2010; Hooker \& Young 2010). Hiermee wou hulle dit duidelik stel dat die kerk- en volksgrense nie kan saamval nie. Jesus se oproep dat sy volgelinge selfs hulle eie familielede moet verlaat (Matt 10:37) dui tog onmiskenbaar op die verwagting dat die kerk nie die funksie van legitimeerder van nasionale aspirasies kan vervul nie. Die gedagte dat die kerk en volk duidelik onderskeie werklikhede is, word treffend beliggaam in die verskynsels van katakombes en begraafplase. ${ }^{5}$ Vir eeue lank het Christene besef dat broers en susters in die geloof baie belangriker is as die broers en susters van die stam of vaderland. Die al groter wordende neiging om gedenkmure by kerkgeboue op te rig moet positief waardeer word. Op hierdie manier kan die gedagte van die kerk as 'gemeenskap van gelowiges' nuwe gestalte kry. Die missionêre waarde van só 'n onderneming moet ook nie onderskat word nie. Om kerklos en kerkvyandige mense 'n laaste rusplek op die kerkterrein te gee, laat reg geskied aan die oorspronklike gedagte van 'n 'volkskerk', naamlik 'n missionêre kerk wat gerig bly op die randfigure in die kerk.

Dit is van wesenlike belang dat ons die kritiese vraag vra hoekom ons, maar ook ander Gereformeerde kerke in die

4.Die Brief aan Diognetus, óf Die Diognetus-brief, die pêrel van die apologetiese geskrifte, is 'n anonieme geskrif van' $n$ onseker datum. Navorsers vermoed dat die geskrifte, is ' $n$ anoniem geskrif van ' $n$ onseker datum. Navorsers vermoed dat die
datum van oorsprong tussen 120 en 210 n.C. sou kon wees. Een teorie is dat die
brief die verlore Apologie van Quadratus ( 125 n.C.) kan wees. ' $n$ Ander teorie is dat brief die verlore Apologie van Quadratus ( 125 n.C.) kan wees. 'n Ander teorie is dat
die brief die werk van Pantaenus, die hoof van die kategese skool in Alexandrië kon wees wat dit aan die prokurator Claudius Diognetus gestuur het. ' $n$ Verdere teorie is dat die outeur die leermeester van Marcus Aurelius kon wees en dat hy hierdie brie gebruik het om die Romeine te leer waaroor die Christelike geloof handel. Jefford (1996:162), het selfs die vermoede dat hierdie brief die taak van ' $n$ goeie student kon gewees het. Die teks is bekend deur'n enkele Griekse manuskrip wat bewaar is saam met vier geskrifte van Justinus die Martelaar in die Codex Argentoratensis Grace ix (veertiende eeu). Hierdie kopie is in 1870 in Strasbourg deur ' $n$ brand Grace ix (veertiende eeu). Hierdie kopie is in 1870 in Strasbourg deur ' $n$ brand verwoes (Jefford 1996:159). Daar bestaan groot ooreenkomste tussen hierdie brie en die Apologiee van Aristides, Justinus en Tatianus. Dit is belangrik om op te merk dat die Christendom hier beskryf word as ' $n$ 'unieke volk' wat nie identies is me 'n spesifieke volk nie, wat orals oor woon en 'n unieke lewenstyl handhaaf wat
voortspruit uit die liefde en eskatologiese verwagting (Dulles [1971] 2005:35-37).

5.Cf. Nicolai, Bisconti en Mazzoleni (2000) vir 'n omvattende daarstelling van die katakombes in Rome. 
wêreld (vgl. Van de Beek 2012:114-116), dit nie regkry om die distansie tussen kerk en nasionale strewes te handhaaf nie? Ek huldig die mening dat dit met die gebrekkige begrip van Christelike vryheid - die sentrale begrip van die Reformatoriese teologie (vgl. Melanchthon [1553] 2010:310315; Moltmann [1997] 1999:191-208 en Huber 2007) te make het. Die behoefte om veiligheid te skep in die bekende en die vrees vir ontmoeting met die onbekende maak dat ons nie vry kan wees om in gelatenheid en vreugde die res van die algemene of katolieke kerk te ontmoet as ons ware broers en susters nie. Anders gestel: wie nog nie die vrye broederskap van die katolieke kerk ontdek het nie, sal bly hunker na die onvryheid wat die aardse broederskappe opdis.

Om kritikus te wees, is ' $\mathrm{n}$ gevaarlike spel - onder andere omdat die aanwysbare gestaltes van die kerk aan die verander bly. Die Reformatoriese ekklesiologie gaan van die mening uit dat die kerk vir die wêreld ' $n$ vreemdheid is, en in die wêreld vreemd moet bly. Die kerk is uitgeroep uit hierdie wêreld en sy natuurlike ordeninge uit (Busch 2003:252). Die ironie is egter dat die NHKA (en ander Afrikaanse kerke) vandag funksioneer as 'alternatiewe gemeenskappe'. 'n Mens sou selfs van 'n nuwe vorm van sosiaal-kulturele asketisme kon praat; 'n nuwe sekulêre kloosterwese. Afrikanerkerke is veilige hawens in 'n onsimpatieke omgewing. Die verlange na monokulturele ervarings is groot en die kerke maak hierdie ervarings moontlik. 'Volkskerk' bly dus verkeerd, maar is 'n blywende werklikheid. Dit kan beveg word, maar sal nie weggaan nie. Nuwe wêreld en ou wêreld gaan meelopers bly, en dit lyk my daar is uiteindelik niks daaraan te doen nie. 'Ekklesiologiese sekularisme' (Busch 2010:221), die onblusbare drang wat daar in die kerk bestaan om 'n vennootskap met die wêreld aan te gaan, beur net eenvoudig vorentoe. As ons insien dat daar krities met 'volkskerk' omgegaan moet word, moet ons darem ook insien dat die gestaltegewing van die kerk met behulp van ekonomiese ideale en terminologie nét so verkeerd is. Dinge soos leierskap, korporatiewe identiteit, missie en visie, strategiese beplanning, suksesverhale en prestasies van gemeentes maak van die kerk van Jesus Christus ewe-eens 'n sekulêre instelling - wat natuurlik onaanvaarbaar is.

Hierdie gedeelte word afgesluit met 'n teks van die Wittenbergse reformator, Philipp Melanchthon ([1553] 2010:) wat 'n voortsetting is van die leerinhoud van die Vroeë Kerk:

... das in göttlicher Schrifft von der Kirchen offt also geredt wird, das allein die Heiligen, das ist Gott gefelligen, verstanden werden, welche gemeiniglich genennt werden lebendige Glieder des Heubts und Heilands Christi, Die doch auch eusserliche Zeichen haben, dadurch sie von andern Volckern unterscheiden werde. Als nemlich das reine Evangelium, rechten brauch der Sacrament, bekenntnis rechter Lere, anruffung Gottes in vertrauen uff Christum ... Diss ist der fürnemest verstand, was Kirche sey, nemlich Gottes volck, welches das heilig Evangelium bekennet und dem selbigen folget, die Sacrament recht braucht und durch den heiligen Geist neu geborrn ist ... Dabey sind auch in etlichen Personen zeugnis des heiligen Geists mit tugenden und besondern Wunderwercken, dadurch der name Christi gepreiset wird. (bl. 383; 384; $390=$ HL 527, 9-19; 529, 11-14; 535, 14-18)

\section{Eenheid en katolisiteit van die Kerk Eenheid en verskeidenheid}

Die outeur (vgl. Van Wyk 1999:283-284, 2000) het alreeds in die verlede sy standpunt oor kerklike eenheid gestel. Sy mening het intussen ook nie verander nie. Daar bestaan twee redes hoekom daar weer aan hierdie vraagstuk aandag gegee moet word: (1) die kerkskeuring wat in 2012-2013 in die naam van die 'steedsHervormers' plaasgevind het, en (2) die bewuswording van pluraliteit binne die Kerk selfs ná die kerkskeuring (vgl. o.a. Brayshaw 2012; Labuschagne 2012; D.J.C. van Wyk jr. 2012; Claassen 2013; Redelinghuys 2013; Van Staden 2013; C.J. van Wyk 2013).

Op voetspoor van Calvyn word die volgende weer gestel: Die kerk is die liggaam van Christus en daarom kan daar net één kerk wees. Alle uitverkorenes van God is aan mekaar verbonde deur geloof, hoop en liefde (Inst IV, 1, 2). Die eenheid van die kerk word geglo, maar eenheid is nie ' $n$ saak nét vir die onsigbare kerk nie, maar ook vir die sigbare kerk (Inst IV , 1, 3). Christene moet lewe in ooreenstemming met dít wat hulle glo. Een manier hoe kerklike eenheid bewaar en bevorder kan word, is deur die presbiteriaans sinodale sisteem van kerkregering (vgl. Plasger 2008a:110 111, 2008b:321). Die motief van eenheid was vir Calvyn só oorheersend dat hy selfs nie eers die Roomse Kerk as valse kerk afgeskryf het nie, bloot omdat daar met haar oor 'die ware en regte gestaltegewing van die kerk gestry word nie' ('de vera et legitima ecclesiae constitutione') (Inst IV, 2, 12 = Calvyn [1559] 1992:1315-1316). Hierdie 'byna ineengestorte bouwerk' ('semirutum aedifiium') (Inst IV , 2.11 = Calvyn [1559] 1992:1343) geniet nog steeds God se trouheid en bewaring en daarom moet die eenheid met (selfs) Rome bevorder word. Ons kom dus nie uit ' $n$ kongregasionalistiese kerkordelike tradisie waar menslike belange en politieke ideale kerk-wees bepaal nie (vgl. Van den Brink \& Van der Kooi 2012:526-530). Kerkskeuring moet daarom sterk veroordeel word.

'n Kerkskeuring op grond van belydenisaangeleenthede

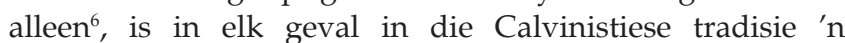
bedenklike aangeleentheid. Wanneer Calvyn oor eenheid en verskeurdheid praat, lig hy nooit 'n belydenisaangeleentheid uit as 'n saak op sy eie nie. Die een keer skryf hy dat eenheid te make het met 'ooreenstemming in die waarheid van die Goddelike leer en verbondenheid in die band van dieselfde Godsverering' ('in unam [...] divinae doctrinae veritatem consentit et eiusdem religionis vinculo colligata') (Inst IV, 1, 9, 10-11 = Calvyn [1559] 1992:1280). 'n Ander keer wys Calvyn ([1559] 1992) daarop dat ons mense:

aslidmatevan diekerk [kan] herken watsowel ingeloofsbelydenis, as in lewenswandel asook deelname aan die sakramente te kenne gee dat hulle een en dieselfde God en Christus saam met ons bely (quo pro Ecclesiae membris agnoscamus qui et fidei confessione, et vitae exemplo, et sacramentorum participatione eundem nobiscum Deum ac Christum profitentur. (Inst IV , 1, 8, 22-23 = Calvyn [1559] 1992:1279)

Belydenis, erediens, sakramente en lewenswyse tesame kan 'n saak word vir afskeiding, maar beslis nie 'n enkele belydenisaangeleentheid alleen nie.

6.Die steedsHervormers is tans besig om die NHKA te skeur met die argument dat sy één 'leerdwaling' in haar midde duld - (vgl. I.W.C. van Wyk 2011:6-8). 
Die vraag is op hierdie stadium wat gesê en gedoen moet word in die lig van die kerkskeuring in die NHKA? Ek meen Bram van de Beek het die regte oordeel oor sake. Hy herinner daaraan dat kerkskeuring altyd deur predikante aangedryf word. Wat daar agter lê het Tertullianus al geweet. Dit is die 'haantjesgedrag van mensen die streven naar het bisschopsambt' (Tertullianus, De baptismo 17, soos gelees kan word in Migne 1844-1864, 1:1218; vgl. ook Van de Beek 2012:147). Nadat die haantjies die kerk verlaat het, blyk dit dat hulle waarskynlik nooit eers predikante moes word nie. Wat die Kerk moet doen, is vir hom duidelik. Sy moet alles moontlik doen om die verloopte lidmate uit te nooi om terug te kom en om die predikante wat berou betoon, nuut te orden (Van de Beek 2012:146-150).

Die moeiliker vraag is hoe ons met die pluraliteit in die Kerk moet omgaan in die lig van die eis dat alles moontlik gedoen moet word om eenheid te bewaar en te bevorder? Johannes á Lasco (Busch 2010:230) was die eerste persoon wat op grond van Galasiërs 3:28 gepraat het van 'versoenende verskeidenheid'. Volgens hom is almal in Christus een, al kom hulle uit totaal verskillende agtergronde en kultuurgroeperings. Volgens á Lasco moes die verskeidenheid onderbeklemtoon word om die eenheid te waarborg. Die NHKA se probleem is dat marginalisering subtiel plaasvind. Bepaalde individue en groeperings word stilweg tot op die rand van die kerklike lewe gedruk. Die eenheid sal op die lange duur nie bewaar kan word, as die verskeidenheid nie gerespekteer en geakkommodeer word nie. 'Versoenende verskeidenheid' moet die banier wees waaronder veelstemmigheid en meningsverskil in die Kerk verduur word. Dít kan gebeur deur ruimte te bied vir vrye assosiasie in onafhanklike teologiese byeenkomste (wat nie kerkies binne die kerk is nie).

\section{Katolisiteit}

Ons bely dat die kerk 'katoliek' is. Wat dit beteken is nie so seker nie. Die kerkvader, Ignatius (110 n.C.) het in $A d$ Smyrnaeos 8 (vgl. Van de Beek 2012:69 = Migne 1857-1866, 5:713) gesê: 'Waar Jesus Christus is, daar is die katolieke kerk.' Hy het bedoel; waar die biskop is en die Nagmaal uitdeel en waar die volheid van die heil in Christus beleef word, waar gebid word en vergewing van sondes, die goedheid van die Vader en die opstanding van Christus ervaar word, dáár is die kerk. Met katolisiteit het hy dus die volheid van die lewe in Christus bedoel.

Cyprianus was die eerste kerkvader wat die term 'katoliek' gereeld gebruik het. Vir hom het dit gegaan oor eenheid en vrede. Wanneer daar 'eenheid in die kerk is, is daar katolieke vrede' (Van de Beek 2012:70). Op grond van die algemene gebruik van die term, is dit eventueel in die geloofsbelydenis opgeneem deur die Konsilie van Konstantinopel (381 n.C.). Interessant is dat min uitleggers van die Credo hieraan aandag gegee het. Die eerste was Cyrillus van Jerusalem (348 n.C.) in sy Kategetiek Lesings XVIII, 23 (Van de Beek 2012:7071 = Migne 1857-1866, 33:1044). Volgens Cyrillus word die kerk katoliek genoem omdat dit: (1) uitgestrek lê oor die hele aarde, (2) alle dogmata leer aangaande die sigbare en onsigbare dinge, (3) uit alle lae van die samelewing bestaan, (4) universeel elke soort sonde, van liggaam en gees, behandel en genees, en (5) alle deugde en gawes besit en beoefen.

'Katolisiteit' is geen empiriese werklikheid nie, maar hierdie kenmerk van die kerk plaas 'n morele verpligting op ons en funksioneer as 'n rigsnoer vir die eie kerklike lewe. Die NHKA sal minstens aan die volgende sake aandag moet gee:

Die kerk is wêreldwyd: NHKA verstaan haarself as 'volkskerk'. Vir dekades lank beskuldig ander kerke ons dat die gangbare uitleg van hierdie konsep in die NHKA, nasionalisties en selfs rassisties is. Die konsekwensie van die volharding met hierdie vreemde uitleg van 'volkskerk' is dat ons soos 'n sekte funksioneer, en as gevolg van die isolasie, geestelik en teologies verarm het. Die ontdekking van die katolisiteit van die kerk behoort ons uit die selfopgelegde isolasie te help.

Die gehele leer: Elke kerk wat daarop aanspraak maak om kerk van Christus te wees, moet aan al die aspekte van die Christelike geloof aandag gee. Die beste manier om dít te doen is om in kerk en universiteit noulettend die uitgebreide liturgiese kalender te volg (vgl. N. van Wyk 2012).

Alle vlakke van die samelewing: Die NHKA is ' $\mathrm{n}$ kerk vir die middelklas. Sy kry dit nie reg om byvoorbeeld die armblankes in kerklike aktiwiteite te betrek nie. Ons sal by die Vroeë Kerk en die Afrika kerke moet gaan leer wat gasvryheid beteken.

Alle sondes: Die NHKA het dit nog altyd ongemaklik gevind om oor sekere sondes te praat. Daar is byvoorbeeld selde oor die bosoorlog en die sondes van die oorlog gepraat. 'n Groot aantal oudsoldate sterf een na die ander met verterende skuldgevoelens en verbittering. 'Volkskerk' sou legitiem wees indien dit die pastorale moeder vir 'n bepaalde groep mense is waar daar oor al die sondes gepraat kan word.

Alle deugde en gawes: In die NHKA heers daar stryd en konflik oor talle sake. Daar is maar min sprake van liefde, onder andere omdat die vertel van halwe waarhede tot deug vervolmaak is. 'n Kerk wat die liefde vir die waarheid verloor het, huigel wanneer sy die katolisiteit van die kerk bely.

Cyrillus se omskrywing van katolisiteit kon in die geskiedenis nie standhou nie. Die kerkskeurings tussen die Westerse en die Oosterse Christendom het die ideaal van 'n wêreldomspannende kerk vernietig. Een eeu na die dood van Cyrillus het ' $n$ Franse monnik, Vincentius van Lerinum, die volgende rigtinggewende verklaring van 'katoliek' gegee: 'In die katolieke kerk moet daar tot die uiterste daarvoor gesorg word dat ons vashou aan wat orals en altyd deur almal geglo is' (my vertaling van Commonitorium 1,2; Van de Beek 2012:86 = Migne 1844-1864, 50:640). Hierdie uitleg het in die Weste die riglyn vir die verstaan van hierdie belydenis geword. Die historiese werklikheid was (en is) egter dat byna almal aan bepaalde aspekte van die evangelie geglo het. Vincentius het dít geweet en met 'n unieke oplossing na vore gekom. Hierdie waarheid waarin byna almal glo kan 
nie deur die meerderheid vasgestel word nie. Daar kan nie gehoop word op 'n konsensus wat geskep sou kon word nie; nee - die outoriteit van die bronne en die tradisie moet aanvaar word. Daarom moet katolisiteit verstaan word vanuit die perspektief van die apostolisiteit. Ek meen dat Vincentius se verstaan van katolisiteit vir die NHKA ook van groot waarde behoort te wees. Ook ons moet leer om terug te keer na belangrike historiese bronne. Belydenis en besinning oor belydenis kan net gedoen word deur met erns belangrike historiese bronne te bestudeer - en dít kan net in samewerking met ander kerke in die wêreld gedoen word. Ek staan egter skepties teenoor die Gereformeerde gedagte (Van den Brink \& Van der Kooi 2012:567) dat die katolieke geloof 'in dít wat nog altyd geglo is' te make het met die universele strekking van die een evangelie, óf anders gestel 'aanspraak maak op die universele geldingskrag van die evangelie.' Dat alles in die maatskappy onder die hoofskap van Christus moet kom, is net nie meer ' $n$ realistiese ideaal vir Suid-Afrika nie. Gereformeerde kerke se invloed kan nie meer tot uiting kom in maatskaplik-politieke programme nie. Om hierdie rede moet ons terugkeer tot die aanvanklike Calvinistiese idees oor katolisiteit soos wat ons dit onder andere in die Confessio Scotica (1560), Hoofstuk XVI vind:

As we believe in one God ... so we firmly believe that from the beginning there has been, now is, and to the end of the world shall be, one Kirk, that is to say one company and multitude of men chosen by God, who rightly worship and embrace Him by true faith in Christ Jesus, who is the only Head of the Kirk ... This Kirk is Catholic, that is, universal, because it contains the chosen of all ages, of all realms, nations, and tongues ... who have communion and society with God ... Out of the Kirk there is neither life nor eternal felicity ... This Kirk is invisible, known only to God ... and includes both the chosen who are departed, the Kirk triumphant, those who yet live and fight against sin and Satan, and those who shall live hereafter. (Cochrane 2003:175)

\section{Die ampte van predikant en gemeentelid}

Die NHKA staar die werklikheid in die gesig dat sy in die nabye toekoms weer 'n tekort aan predikante gaan beleef. In sinodale rade word die gedagte dikwels geopper dat die oplossing voorhande is in die ontwikkeling van die 'priesterskap van die gelowiges' of die 'amp van die gemeentelid' (Kraemer [1960] 1962). Hierdie standpunt moet skepties bejeën word. In die eerste instansie kan gemeentelede nie sonder predikante gemeentes in stand hou nie. In die tweede instansie is dit ' $n$ teologies oningeligte opinie wat die amp van predikant geringskat. Binne die beskikbare ruimte word Martin Luther se gedagtes oor die 'priesterskap van die gelowige' onder die aandag gebring. Die rede: daar word verkeerdelik geglo dat hy die 'priesterskap' ten koste van die predikantsamp bevorder het.

Dit is te verstane dat Luther in die beginjare van die Reformasie positief gedink het oor die 'priesterskap van die gedooptes'. Daar is geen twyfel daaroor dat hy groot verwagtinge gehad het oor die positiewe rol wat gemeentelede sou kon speel nie. Hy het alreeds in sy lesings oor die Romeinebrief in 1515-
1516 (Luther WA 56, 251, 25-27) 'n radikale uitspraak in hierdie verband gemaak: 'Elke woord wat uit die mond van ' $n$ kerkleier of ' $n$ vroom en heilige man kom, is die woord van Christus ....' (my vertaling). Sedert sy Sermon von dem Neuen Testament (1520) het hy begin om die 'leer oor die priesterskap van die gedooptes' te verduidelik en te verdedig.

Hoekom het Luther die leer oor die priesterskap van alle gedooptes ontwikkel? Hy het dit gedoen weens sy magteloosheid jeens die Rooms-Katolieke Kerk (RKK). Hy het gekla dat die ampshiërargie van die RKK hulle teologies op drie maniere beveilig het. In 1520 kla hy in An den christlichen Adel deutscher Nation von des christlichen Standes Besserung (Luther WA 6, 406, 23-29) dat hulle die volgende drie mure om hulle geplaas het: (1) 'n Regsmuur wat steun op die howe wat deur die politieke owerhede beheer word en wat deur die RKK beïnvloed word, (2) 'n teologiese muur wat stel dat slegs die ampte van die kerk die Bybel kan uitlê, en (3) 'n muur van kerklike strukture wat gebruik maak van die argument dat die pous die laaste sê in kerklike en teologiese sake het. Hierteenoor beweer Luther dat daar nie 'n onderskeid tussen die geestelike en wêreldlike stande is nie. Almal is as gelowiges gelyk. Niemand is as gelowige belangriker as 'n ander een nie. Wat jy by die doop ontvang, maak van jou 'n priester, biskop en pous. Alle Christene is van die geestelike stand; daar is geen onderskeid nie, almal is ampsdraers.

Die vraag is natuurlik wat Luther onder die uitdrukking 'algemene priesterskap van gedooptes of gelowiges' (soms gebruik hy die een en soms die ander uitdrukking - vgl. Lohse 1995:309; Bayer 2003:248) verstaan? Eerstens, beteken dit dat mense nie 'n priester benodig om tussen hulle en God te bemiddel nie. As gelowiges het hulle direkte toegang tot God. Tweedens, het gelowiges die reg om aan medegelowiges die vergewing van sondes te verkondig (dit is nie die voorreg van die priester alleen nie). Derdens, kan een gelowige teenoor ' $n$ ander gelowige bieg. Laastens, dat ' $n$ Christelike gemeente die reg en mag het om die predikant se leer te beoordeel, 'n leraar kan beroep en hom uit die amp te onthef (Lohse 1995:310).

Luther het dit nooit in gedagte gehad dat die algemene priesterskap die besondere amp van predikant moes vervang nie. Die positiewe uitsprake oor die 'priesterskap' moet binne konteks verstaan word. Dit was nie deel van 'n grondige, sistematiese deurdenking van die ampte nie. Luther het hom eers in sy latere geskrifte (Von den Konziliis und Kirchen - 1539 en Wider Hans Worst - 1541) duidelik en omvattend oor die saak van die amp uitgelaat. In beide geskrifte het hy die besondere amp selfs as 'n kenmerk van die ware kerk beskryf. Hy het selfs in daardie tyd van konflik, waardering vir die biskopsamp uitgespreek (Lohse 1995:306). Sy onwrikbare geloof in die amp van leraar het verband gehou met die primêre opdrag van die predikant, naamlik dié van 'Woordverkondiging' en sakramentsbediening. Gewone lidmate kon volgens hom nie hierdie funksies oorneem nie.

As Luther na 'priester' verwys, gebruik hy die Latynse woord sacerdos. As hy na die amp verwys, gebruik hy die woord minister. Luther het nooit minesterium vir die algemene 
priesterskap gebruik nie. Die 'priester' was vir hom nooit die ampsdraer nie. Elkeen is 'n priester deur die doop, terwyl die ampsdraer deur God geroep (vocatio) word (Luther WA 12, 178, 9-10 Sacerdotem non esse quod presbyterium vel ministerium; illumnasci, hunc fieri). In 1530 (in sy uitleg van die Psalm 82 Luther WA 31,I,211,17-20) stel hy dat alle Christene priesters is, maar dat nie almal ampsdraers is nie. Die beroep en die bevel maak van sekere Christene predikante. Volgens Luther moet daar ' $n$ besondere amp wees wat verantwoordelik is vir die openbare Woordverkondiging. Sou daar nie so 'n amp wees nie, sal daar chaos wees, en wanorde is nie gepas vir die kerk van die Here nie (Bayer 2003:250).

Om saam te vat: elke gedoopte lidmaat het 'n verantwoordelikheid jeens die kerk en die evangelie. Gemeentes het egter geordende predikante nodig. As daar 'n tekort is, moet daar kreatiewe oplossings kom, sou Luther geargumenteer het. Een vanselfsprekende oplossing is om emeritaat los te wikkel van die administratiewe reëls van die pensioenfonds. Om mense se ampstermyn arbitrêr op 65 te termineer is nie wys nie.

'Priesterskap' van die lidmaat is vandag wel, om ander redes as hierbo, 'n belangrike saak. In 'n demokratiese kultuur, waar vryheid van spraak en toleransie as belangrike waardes geag word, is dit uiters noodsaaklik dat alle lidmate oor die evangelie sal praat en skryf. Dit kan nie aan 'n paar teoloë en kerkleiers oorgelaat word nie (Theißen 2012:280-283). Dit is juis die lidmate wat in ons huidige politieke bedeling maatskaplike verantwoordelikheid moet neem om toe te sien dat almal se menseregte en menswaardigheid gerespekteer word (Huber 2009:174-175).

\section{Koninkryk, sending en publieke rol van die Kerk Koninkryk}

Aan die begin van die twintigste eeu het A. Loisy hierdie veel gesiteerde uitspraak gemaak: 'Jesus het die ryk van God verkondig, en toe kom die kerk.' Daar word soms gedink dat hierdie uitspraak 'n kerkkritiese uitspraak is wat mense aanmoedig om net op die 'koninkryk' te fokus. Loisy se stelling was egter ironies bedoel. Die negentiende eeu se teologie het gedink dat die samelewing méér gebied kan word as wat die kerk op daardie stadium wel gedoen het. Die argument was dat 'gefokus op die koninkryk' welmenende Christene, beter sosiale omstandighede kan help skep. Hieroor was Loisy bra skepties. Karl Barth, die Nederlandse apostolaatsteologie en Jürgen Moltmann het egter met hierdie ideaal volhard. Die outeur, in navolging van hierdie leermeesters, was vir byna twee dekades lank besig met 'missionêre diakonaat'. Die kritiese vraag is, wat het hierdie 'bouwerk aan die koninkryk' uiteindelik opgelewer? Om eerlik te wees - baie min.

As ons oor die koninkryk wil praat, moet ons daaroor praat soos wat Jesus ons geleer het om te doen, naamlik om te bid vir sy koms. Luther het die tweede bede soos volg in sy Klein Kategismus uitgelê:
What does 'the kingdom come' mean? The kingdom of God comes indeed without our prayer, of itself. But we pray in this petition that it may come to us also. How is this done? When our heavenly Father gives us His Holy Spirit, so that by His grace we believe His holy Word and lead a godly life here in time and there in eternity. (Concordia 2005:359)

Die koninkryk sal dus kom as die Woord van God geglo word soos wat dit deur die prediking na ons toe kom. Heinrich Bullinger skryf in die Confessio Helvetica posterior (1566) 'Die prediking van die Woord van God, is die Woord van God' ('praedicatio verbi Dei est verbum Dei'). Hiermee bedoel hy dat die prediking iets meedeel wat ons nie vir onsself kan vertel nie. Prediking is ook nie bloot uitleg (veral selfuitleg) nie; dit is ook meedeling van 'n vreemde boodskap. Om hierdie rede is prediking onlosmaaklik aan die werk van die Heilige Gees gekoppel. Vir dieselfde rede kan prediking ook nie bestaan uit die blote herhaling van (belydenis en leer) formulerings van die verlede nie (Van den Brink \& Van der Kooi 2012:535-538).

\section{Sending}

Binne die beskikbare ruimte kan die volgende paar belangrike opmerkings oor sending (en evangelisasie) gemaak word. Apostolaat (die voorkeurterm in die NHKA vir sending) moet aan apostolisiteit gekoppel bly. Elke poging om die evangelie aan diegene op die rand van of buite die kerk oor te dra, moet getrou bly aan die inhoude wat die apostels geleer het. In sendingpogings, soos eietydse apologetiese gesprekke, mag daar nie van die fundamentele geloofsoortuigings afgewyk word nie. Ook in sendingpogings moet daar by die kernsake van die belydenis gebly word. Hiermee word natuurlik nie ' $n$ teologiese konserwatisme bepleit nie - soos dié van die Oosterse Kerk wat vashaak by die formulerings van Johannes Chrysostomus en Maximus Confessor nie. Ons móét die ou dinge vandag nuut formuleer, maar die nuwe formulerings moet nie só nuut wees dat dit nie meer die ou boodskap verwoord nie (Van de Beek 2012:92-96). Christene moet mekaar hierin help. Daar moet toegesien word dat die verkondigde en gedoseerde evangelie in ooreenstemming met die boodskap van apostels (Rom 10:14-15) bly. Binne die Hervormde tradisie lê hierdie verantwoordelikheid by die kerkraad (magisterium) en die sinode met sy kuratorium (Van den Brink \& Van der Kooi 2012:567). 'Missionale gemeentes' buite die grense van die apostolisiteit sal niks standhoudend oplewer nie!

Daar word in die NHKA té veel van die missionaat verwag. In sekere kringe is die verwagting groot dat die Kerk op grond van missionêre projekte weer sal groei en op hierdie wyse die finansiële krisis die hoof sal kan bied (vgl. Beukes 2012 vir die verwysings). Hierdie verwagting berus op'n misverstand -'n misverstand oor die wese van sending. Vanselfsprekend het sending met die hartklop van die evangelie te make. Sonder sending sterf ' $n$ kerk, maar sending het nie te make met dít wat ons kan vermag nie. Sending kan nie probeer verwerklik wat God nog moet doen nie. Dit kan slegs uitgaan van wat God reeds gedoen het, naamlik om Christus en wêreld byeen te bring. Ons kan slegs getuienis aflê van die lig wat in ons 
duister wêreld gekom het; ons kan die lig nie skep nie, en kan dit ook nie wees nie (Jüngel [1999] 2003:121-127). Ons sal moet leer om die Heilige Gees te vertrou om 'n gemeente te bou waar daar oor die Lig en die Lewe getuig word en waar daar as en soos mense van die lig gelewe word.

Vir dekades lank word daar in die NHKA oor 'volkskerk' gestry. Hierdie stryery het gekom omdat ons van die oorspronklike Nederlandse verstaan van hierdie konsep afgewyk het en iets daarvan gemaak het wat teologies moeilik verdedig kan word (bv. Van der Westhuizen 1981). Sending as die poging om 'volke te kersten' of te 'verchristelik' is in stryd met die gedagte dat die kerk die 'derde volk' is. Die idee van ' $n$ 'Christelike volk' kon in 1960 dalk nog sin gemaak het, maar in 2013 is dit 'n vreemde gedagte. 'Volkskerk' was oorspronklik 'n missionêre begrip. Die Hervormers in Nederland wou met die hele gedoopte Nederlandse bevolking kontak behou. Op grond van 'n 'verkondigingsteokrasie' (Van den Brink \& Van der Kooi 2012:572-573) wou hulle die evangelie dien in 'n samelewing wat al meer gesekulariseerd geraak het. Diegene op die rand van die kerk is steeds as lidmate beskou. Formele lidmaatskap het die moontlikheid oopgehou van 'n oop deur vir die ampsdraers van die kerk. ' $n$ Kerk wat gerig bly op alle gedooptes in die volk is legitiem. 'n Kerk gerig op slegs die eie volksgenote is menslik goed te verstane, maar teologies illegitiem. Die sancta ecclesia, die communio sanctorum is 'n gemeenskap van gelowiges wat mense uit die heidendom uitnooi om in hierdie gemeenskap te deel en daar mag nie aan maatreëls gedink en gewerk word om sommige genooides buite te hou nie. 'n Kerk wat dít doen is nie 'n ware 'volkskerk', 'n 'sendingkerk' nie (Van Wyk 1995; Busch 2003:228, 260-262).

Wat kan 'n 'volkskerk', of 'n 'missionale kerk' dan vandag doen? Die kerk se klok moet gelui word - al kla ons gesekulariseerde volksgenote; die deure moet oop bly - al is dit onveilig; die ouderlinge moet na afloop van die erediens bid vir die uitdra van die evangelie - al weet ons dat daar nie meer by ons huise daaroor gepraat word nie; ons moet kos gee vir dié wat nie het nie - al weet ons dat die gemeentelede hierdie mense nie met ope arms wil ontvang nie; ons moet mense begrawe met behulp van die taal van die Bybel en die rituele van die kerk - al het sommige predikante nie meer geloof in die taal van die Bybel nie en wil die begrafnisgangers hulle eie rituele skep (vgl. Huber 2009:171). Daar is seker baie nuwe dinge wat ook gedoen kan word, maar as die ou dinge, die vanselfsprekende dinge nie meer gedoen word nie, sal daar niks 'positief' gebeur nie.

\section{Taak van die kerk in die samelewing}

Soos die kerke in Europa dekades gelede ontdek het dat hulle openbare rol vervaag het, besef ons in Suid-Afrika al meer en meer dat ons in 'n land lewe waar die kerklike era ook verby is. Dit sal ons daarom goed doen om kennis te neem van die huidige debat in Nederland oor die publieke rol van die kerk. Twee resente Nederlandse publikasies verdien ons aandag, die een van Dekker (2010) en die ander een van Kennedy (2010).
Die godsdienssosioloog, Gerard Dekker (2010:11-14) sê dat 'die kerk homself in vele opsigte self oorleef het.' Daarmee bedoel hy dat die kerk in Nederland haarself al meer en meer van haar eie roeping vervreem het. Hy kritiseer die oordrewe klem wat die kerk geplaas het op haar publieke rol in die samelewing. Hierdie rol het primêr te make met die lewering van maatskaplike dienste. Volgens Dekker kon die ou 'volkskerk' hierdie rol vervul aangesien daar orals in Nederland gemeentes was waarby die grootste gedeelte van die volk betrokke was. Binne die nuwe Nederlandse werklikheid waar die kerk 'n minderheid verteenwoordig, is hierdie rol nie meer te handhaaf nie. Die kerk is nie meer die primêre diensverskaffer nie. Sy kan hierdie dienste alleenlik bly lewer in samewerking met sekulêre instellings - en in talle gevalle as die junior vennoot. Dekker argumenteer dat die kerk van hierdie uitgediende rol moet afsien, om weer te konsentreer op die eintlike taak van die kerk, naamlik die 'rituele begeleiding bij de scharnierpunten van het leven, zoals geboorte, huwelijk en overlijden' (Dekker 2010:17). Hy bepleit 'n 'inventiewe capitulatie' sodat die kerk weer op haar eie besigheid kan konsentreer, naamlik omgang met God en sy Woord (2010:20-27). Die kerk kan nie net 'n nuttige maatskaplike instelling wil wees nie. Sy moet weer 'missionêre kerk' word wat konsentreer op sending, bekering en gemeentevorming (2010:25). Sy moet toesien om weer ' $\mathrm{n}$ 'cultuurvormende' krag te word en daarvan afsien om 'n bloot 'cultuurvolgende kracht' te wees (2010:58) - met ander woorde, om die moderne gemeenskap na te aap en na te praat. Volgens Dekker (2010:219-220) moet die kerk die 'profanisering van die heilige en die sakralisering van die wêreld voorkom' deur koers te laat aandui deur Christelike vakmanne en deskundige kerklidmate wat bereid is om op te staan vir die wesenlike van die evangelie. Om mense daartoe te bemagtig moet die kerk fokus op haar 'kernaktiwiteite', sonder om 'newe-aktiwiteite' heeltemal agterweë te laat.

James Kennedy (2010:7-19) maak in sy boek oor die publieke rol van die kerk ook 'n paar insiggewende opmerkings. Hy merk op dat die kerk 'n 'eienaardige instansie' is wat maatskaplike, sosiale en diakonale dienste lewer, maar tegelyk ook 'n 'spirituele instansie' is wat eredienste hou en klokke lui. Die kerk is met ander woorde ook 'n 'bowe-maatskaplike instansie'. Hierdie instansie is egter besig om al meer en meer uit die samelewing te verdwyn omdat godsdiens in Nederland 'n privaat aangeleentheid geword het. Godsdiens het met individue se innerlike lewe te make omdat die sekularisasieprosesse die kerk uit die openbare lewe gedruk het. Hy sien die toekoms van die kerk as 'n 'kontras-gemeenskap', 'n instansie as deel van die wêreld van die subkulture. Die kerk as kulturele instelling moet iets anders, 'n alternatief aanbied op dít wat die kulturele hoofstroom kan aanbied. Die kerk moet haarself aanbied as 'n gemeenskap met dissipline en lewenstyl, 'n omgeegemeenskap wat aan die massas eensame individue 'n tuiste bied. Hierdie gasvryheid wat benodig word om 'n waarlik inklusiewe gemeenskap te vorm, kom na vore uit 'n alternatiewe visie op die toekoms. Volgens Kennedy (2010:144-151) word 'n gasvrye, inklusiewe gemeenskap dáár gevorm waar daar op 'n hoopvolle wyse met die dood 
omgegaan word. Hierdie hoop word gebore uit die ou taal van die Bybel en die kerklike tradisie wat op 'n verstandige wyse verduidelik en bemiddel word.

Wat leer ons by ons 'moederkerk' wat reeds deur die probleme is waarmee ons nou gekonfronteer word? Dat daar nie afstand geneem moet word van die 'twee-ryke leer' nie (soos wat ek reeds lankal bepleit vgl. Van Wyk 1996). Die regimen spirituale en regimen politicum moet twee onafhanklike terreine van invloed bly. Die kerk moet nie probeer om die rol van die staat oor te neem nie, óf om saam met die staat staat te wees nie, óf om met behulp van die staat 'n rol in die staat te speel nie. Die kerk moet 'n unieke, heilige gemeenskap bly. Haar grootste taak is om haarself te bly (Plantinga et al. 2010:348-353). Die Hervormde Kerk is kerk van die Woord. Ons grootste taak is om nie in die weg van die Woord te staan nie. Mense wíl die Woord hoor. Ons taak is om die kwaliteit van ons eredienste, kategese en Bybelstudies te verbeter. Ons besorgdheid moet nie konsentreer op strukture wat behou en/ of verander moet word nie, maar op ons getrouheid teenoor die evangelie. Waar'n gemeente dit vir ander aanloklik maak om gemeenskap met Christus en sy volgelinge te beleef; dáár is waarlik kerk (Huber 2009:146-151).

'n Laaste los, maar wesensbelangrike gedagte is dat daar tog nie gepoog moet word om die kerk en evangelie relevant te maak nie. Dit ís relevant! 'n Relevant gemaakte evangelie is nie meer die evangelie nie sê Van de Beek (2012:112) tereg.

\section{Samevattende slotwoord}

Ons bevind ons in ' $n$ tyd van groot verwarring en onsekerheid. Op 'n tipiese modernistiese wyse (vgl. Van de Beek 2012:176-184) probeer ook ons om iets aan die situasie te doen. Ons het rapporte, taakspanne, omvattende visies en missies wat ons in beweging moet kry om iets te gaan doen. Hierdie doen loop in talle gevalle dan daarop uit om iets te gaan doen wat die 'evangelicals' doen. Vooruitgang, sukses en prestasie het reeds die slagspreuke in ons eie sosiale media geword. Die kerk word aangemoedig om 'n gemeenskap van voortreflike, suksesvolle doeners te word. Op hierdie wyse word die Christelike geloof uitgehol en verlaat mense hulle al meer en meer op bygeloof en magie. Die NHKA gaan nie met 'n nuwe kultuur van sukses gered word nie. Wat ons eerder moet doen, is om getrou aan ons tradisie, gewoon te doen wat van ons verwag word.

Die Tweede Helvetiese Geloofsbelydenis (1566), opgestel deur Heinrich Bullinger (1504-1575), kan as 'n omvattende samevatting van die hoofelemente van die Hervormde ekklesiologie beskou word. 'n Kort opsomming van die ekklesiologie van hierdie belydenisskrif kan die NHKA help om op die voetspoor van haar eie tradisie te besin oor die uitdagings op haar pad: Die kerk het nog altyd bestaan en sal altyd bestaan. Die kerk is ' $n$ gemeenskap van gelowiges, uitgeroep uit die wêreld, om burgers van een, nuwe gemenebes te vorm. Hierdie een kerk is katoliek, óf is geen kerk nie. Die kerk is militant en triomferend tegelyk. Daar is 'n variasie van gemeentes wat saam één kerk vorm. Die kerk onderskei slegs tussen twee groepe, naamlik gelowiges en ongelowiges. Die een en dieselfde kerk is die tuiste vir ou en nuwe lede (Jode en heidene). Die kerk is die tempel van die lewende God, waarvan Christus die enigste Hoof is. In die kerk behoort daar nie wanorde te heers nie. Die kentekens van die ware kerk is belydenisgetroue prediking en die bediening van die sakramente sonder magiese verwagtinge. Buite die kerk is daar geen saligheid nie. Die ware kerk is nie beperk tot haar kentekens nie, aangesien God se verkiesing verder strek as ons waarnemingsvermoë. Op grond van menslike waarneming mag dit op stadiums lyk of die kerk verdwyn, maar sy bly altyd onder die beskerming en versorging van Jesus Christus. Nie alle lidmate is deel van die ware kerk nie, aangesien nie almal die evangelie glo nie. Eenheid kan nie in rites en rituele gevind word nie. Eenheid is in geloof, belydenis en liefde. God gebruik predikante om die kerk te bou. Hierdie amp moet nie verkleineer word nie. Die ampsdraers moet egter uitnemende mense wees, wat Christus as die groot leermeester navolg. Naas geordende predikante, is die priesterskap van die gelowiges ook belangrik. Dit is die taak van die predikante om die geheimenisse van die koninkryk oop te breek. Hulle mag moet altyd beperk word. Hulle moet verkondig, vertroos en beskerm. Daarbenewens moet hulle die eenheid bewaar en bevorder, kategese aanbied en siekes en armes versorg. Strydlustige mense hoort nie in die amp nie. Ten spyte van wat gesê is, kan selfs booswillige predikante die Woord verkondig, aangesien die Woord se werking nie afhang van die vroomheid van mense nie. Sinodes het die verantwoordelikheid om die leer en lewe van predikante te toets en valse leraars uit die amp te onthef. Gemeentes moet toesien dat alle predikante finansieel versorg word (Cochrane 2003:261-277).

\section{Erkenning Mededingende belange}

Die outeur verklaar dat hy geen finansiële of persoonlike verbintenis het met enige party wat hom nadelig kon beïnvloed in die skryf van hierdie artikel.

\section{Literatuurverwysings}

Barnard, D., 2013, 'In biddende afhanklikheid', Die Hervormer 106(3), Junie, 1. Bayer, O., 2003, Martin Luthers Theologie: Eine Vergegenwärtigung, Mohr, Tübingen. Berger, P., 2004, Questions of faith: A sceptical affirmation of Christianity, Blackwell, Oxford. http://dx.doi.org/10.1002/9780470774762

Beukes, D., 2012, 'Die Hervormde Kerk en die pad vorentoe', Die Hervormer 105(7), Oktober, 1.

Beukes, J., 2012, 'Die Hervormde Kerk in 'n krisis', Die Hervormer: Teologiese Gesprek, 09 Oktober, besigtig 05 Mei 2013, by http://hervormer.co.za/gesprek/index.php/ alle-bydraes/5-die-hervormde-kerk-in-\%E2\%80\%99n-krisis.html

Brayshaw, N., 2012, 'Steeds 'n Hervormer vs steedsHervormer(s)', Die Hervormer 105(6), September, 7

Busch, E., 2003, Credo: Das Apostolische Glaubensbekenntnis, Vandenhoeck, Göttingen.

Busch, E., 2010, Drawn to freedom: Christian faith today in conversation with the Heidelberg Catechism, transl. W. Rader, Eerdmans, Grand Rapids.

Calvyn, J., [1559] 1968, 'Opera Selecta', in P. Barth \& G. Niesel (reds.), Bd IV, Institutionis Christianae religionis, librum III continens, Editio tertia emendata, [s.n.], [s.I].

Calvyn, J., [1559] 1992, Institusie van die Christelike Godsdiens, deel 4, vertl. H. Simpson, Calvyn Jubileum Boekefonds, Potchefstroom.

Claassen, K., 2013, 'Die Here het vir ons ruimte gemaak', e-Hervormer 6(6), 14 Maart, 4, besigtig 05 Mei 2013, by http://www.hervormer.co.za/images/eHervormer_14_03_13.pdf. 
Cochrane, A. (ed.), 2003, Reformed confessions of the sixteenth century, edited, with historical introductions, by Jack Rogers, Westminster John Knox Press, Louisville.

Concordia 2005, The Lutheran Confessions: A Reader's edition of the Book of Concord transl. W. Herrmann, T. Dau \& G. Bente, revised, updated and annotated by P. McCain, Concordia Publishing House, Saint Louis.

Cyprianus, 'De unitate ecclesiae', in J-P. Migne, 1844-1864, Patrologia Latina [MPL] 4:463-464, Garnier, Parisiis.

Cyrillus van Jerusalem, 'Catecheseis', in J-P. Migne, 1857-1866, Patrologia Graeca $[M P G], 33: 331-418$, Garnier, Parisiis.

Dekker, G., 2010, Heeft de kerk zichzelf overleefd? Beschouwingen over de rol van de kerk in de moderne samenleving, Meinema, Zoetermeer.

Dulles, A., [1971] 2005, A history of apologetics, 2nd edn., Ignatius, San Francisco.

Eckert, W., [1968] 2012, s.v. 'Reformation', in O. Holl (red.), Lexikon der christlichen Ikonographie $(L C l)$, Lizenzausgabe, Wissenschaftliche Buchgesellschaft, Darmstadt, Band 3, bl. 516-522.

Hermelink, J., 2011, Kirchliche Organisation und das Jenseits des Glaubens Eine praktisch-theologische Theorie der evangelischen Kirche, Güterslohe Verlagshaus, Gütersloh.

Hooker, M. \& Young, F., 2010, Holiness and mission: Learning from the early Church about mission in the city, SCM Press, London.

Huber, W., 2007, Im Geist der Freiheit: Für eine Ökumene der Profile, Herder, Freiburg

Huber, W., 2009, Der Christliche Glaube: Eine evangelische Orientierung, Gütersloher Verlagshaus, Gütersloh.

Ignatius, 'Ad Smyrnaeos', in J-P. Migne, 1857-1866, Patrologia Graeca, [MPG], 5:708717, Garnier, Parisiis.

Jefford, C.N., 1996, Reading the apostolic fathers: An introduction, Hendrickson, Peabody. PMid:15275260

Jenkins, P., 2007, The next Christendom: The coming of global Christianity, 2nd edn., Oxford University Press, New York.

Jüngel, E., [1999] 2003, 'Mission und Evangelisation', in Ganz werden: Theologische Erörterungen V, bl. 115-136, Mohr, Tübingen.

Kennedy, J., 2010, Stad op een berg: De' publieke rol van protestantse kerken, Boekencentrum, Zoetermeer.

Kerkvaders, Griekse, kyk J-P. Migne 1844-1864.

Kerkvaders, Latynse, kyk J-P. Migne 1857-1866

Kraemer, H., [1960] 1962, Het vergeten ambt in de kerk: Plaats en roeping van het gewone gemeentelid, 3e druk, Boekencentrum, 's-Gravenhage.

Labuschagne, K., 2012, 'Saam op pad na 'n oplossing', e-Hervormer 5(4), 23 Februarie, 4, besigtig 05 Mei 2012, by http://www.hervormer.co.za/images/eHervormer 23 02_12.pdf

Lohse, B., 1995, Luthers Theologie in ihrer historischen Entwicklung und in ihrem systematischen Zusammenhang, Vandenhoeck, Göttingen. PMCid:PMC185299

Luther, M., 1883, vv., D. Martin Luthers Werke: Kritische Gesamtausgabe, H. Böhlau und Nachfolger, (Weimarer Ausgabe [WA], 65 vols.).

Marquard, O., 2003, Zukunft braucht Herkunft: Philosophische Essays, Reclam, Stuttgart. PMid:12784034

Melanchthon, P., [1553] 2010, Heubt artikel Christlicher Lere. Melanchthons deutsche Fassung seiner Loci Theologici, nach dem Autograph und dem Originaldruck von 1553, R. Jenett \& J. Schilling (reds.) 2. aktualisierte und ergänzteAusgabe, EvangelischeVerlagsanstalt, Leipzig.

Migne, J-P., 1857-1866, Patrologia Graeca, [MPG], Garnier, Parisiis.

Migne, J-P., 1844-1864, Patrologia Latina, [MPL], Garnier, Parisiis

Moltmann, J., [1997] 1999, God for a secular society: The public relevance of theology, transl. M. Kohl, SCM, London.

Nederduitsch Hervormde Kerk van Afrika (NHKA), 2008, Diensboek, Sentik, Pretoria.

Nicolai, V., Bisconti, F. \& Mazzoleni, D., 2000, Roms Christliche Katakomben: Geschichte - Bilderwelt - Inschriften, Wissenschaftliche Buchgesellschaft, Darmstadt. PMCid:PMC1221269
Norris, R , 2010 'Articulating identity (2nd century)', in F. Young. L. Ayres \& A. Louth (eds.), The Cambridge history of early Christian literature, pp. 71-90, Cambridge University Press, Cambridge.

Pannenberg, W., 1993, Systematische Theologie, Band III, Vandenhoeck, Göttingen.

Plantinga, R., Thompson, T. \& Lundberg, M., 2010, An introduction to Christian theology, Cambridge University Press, Cambridge.

Plasger, G., 2008a, Johannes Calvins Theologie - Eine Einführung, Vandenhoeck, Göttingen.

Plasger, G., 2008b, 'Kirche', in H. Selderhuis (reds.), Calvin Handbuch, bl. 317-325, Mohr, Tübingen.

Redelinghuys, M., 2013, 'Voortdurende gesprek, voortdurende bekering', Die Hervormer 106(2), 6 .

Strauss, L., 2013, 'Nabetragting oor die Inligtings- en Besprekingsvergadering', Die Hervormer 106(1), April, 3.

Struwig, E., 2013, 'Finansiële tendense', Die Hervormer 106(3), Junie, 4.

Theißen, G., 2012, Glaubenssätze: Ein kritischer Katechismus, Gütersloher Verlagshaus, Gütersloh.

Tertullianus, 'De Baptismo', in J-P. Migne, 1844-1864, Patrologia Latina [MPL], 1:1197-1224, Garnier, Parisiis.

Ungerer, A., 2013, 'Hoe lyk die kerk in ons wêreld?', Die Hervormer 106(2), 2.

Van de Beek, A., 2012, Lichaam en Geest van Christus: De theologie van de kerk en de Heilige Geest, Spreken over God 2.2, Meinema, Zoetermeer.

Van den Brink, G. \& Van der Kooi, C., 2012, Christelijke dogmatiek, Boekencentrum, Zoetermeer.

Van der Westhuizen, H.G., 1981, Volkskerk en sending, HAUM, Pretoria. PMid:6915768

Van Staden, P., 2013, 'U gee my nuwe krag ...' ', e-Hervormer 6(3), 21 Februarie, 4, besigtig 05 Mei 2013, by http://www.hervormer.co.za/images/eHervormer_21_02_13.pdf

Van Wyk, C.J., 2013, 'Hoe lyk ons mense?', Die Hervormer 106(2), Mei, 1.

Van Wyk, D.J.C. jr., 2012, 'Skeuring of hervorming?' e-Hervormer 5(38), 25 Oktober, 4, besigtig 05 Mei 2013, by http://www.hervormer.co.za/images/eHervormer_25_10_12.pdf

Van Wyk, D.J.C. jr., 2013, 'Maak die beste gebruik van elke geleentheid', Die Hervormer 105(10), Januarie, 1.

Van Wyk, I.W.C., 1995, 'Die gemeenskap van die heiliges', HTS Teologiese Studies/ Theological Studies 51(3), 732-752. http://dx.doi.org/10.4102/hts.v51i3.1430

Van Wyk, I.W.C., 1996, 'Het die kerk 'n politieke verantwoordelikheid: Oor die noodwendigheid en grense van die 'twee-ryke-leer', HTS Teologiese Studies/ Theological Studies 52(4), 765-799. http://dx.doi.org/10.4102/hts.v52i4.1563

Van Wyk, I.W.C., 1999, 'Wat glo ons van die Kerk?', in D.J.C. van Wyk (red.), 20e Eeu Hervormde Teologie, bl. 270-285, Sentik, Pretoria.

Van Wyk, I.W.C., 2000, 'Kerklike eenheid tussen die NHKA en die HKSA', HTS Teologiese Studies/Theological Studies 56(2/3), 623-659. http://dx.doi.org/10.4102/hts. v56i2/3.1761

Van Wyk, I.W.C., 2011, 'Wat is reformatoriese teologie?: Nadenke na aanleiding van 'n kerklike beswaarskrif', HTS Teologiese Studies/Theological Studies 67(3), Art. \#1156, 11 pages. http://dx.doi.org/10.4102/hts.v67i3.1156

Van Wyk, N., 2012, 'A multi-functional Catechism following the Liturgical Calendar', Theology and the Church in South Africa: Journal of the Africa Institute of Missiology 4(1), 40-104.

Van Wyk, W., 2013a, 'Kerklike gesprek in die aanloop tot die 70ste AKV', e-Hervormer 6(9), 11 April, 4, besigtig 05 Mei 2013, by http://www.hervormer.co.za/images/eHervormer_11_04_13.pdf

Van Wyk, W., 2013b, 'Kerkrade praat oor kerkwees in die huidige tyd, e-Hervormer 6(14), 16 Mei, 4, besigtig 05 Mei 2013, by http://hervormer.co.za/images/eHervormer_16_05_13.pdf

Willemse, J., 2012, "n Volkskerk', Die Hervormer 105, 09 Desember, 6.

Willis, J. (ed.), 2002, The teachings of the Church Fathers, Ignatius, San Francisco. 